Virginia Commonwealth University VCU Scholars Compass

2007

\title{
Contemporary Approaches to Critical Thinking and the World Wide Web
}

Melanie L. Buffington

Virginia Commonwealth University, mbuffington@vcu.edu

Follow this and additional works at: http://scholarscompass.vcu.edu/arte_pubs

Part of the Art Education Commons

Copyright (C) National Art Education Association (NAEA)

\section{Downloaded from}

http://scholarscompass.vcu.edu/arte_pubs/3

This Article is brought to you for free and open access by the Dept. of Art Education at VCU Scholars Compass. It has been accepted for inclusion in Art Education Publications by an authorized administrator of VCU Scholars Compass. For more information, please contact libcompass@vcu.edu. 


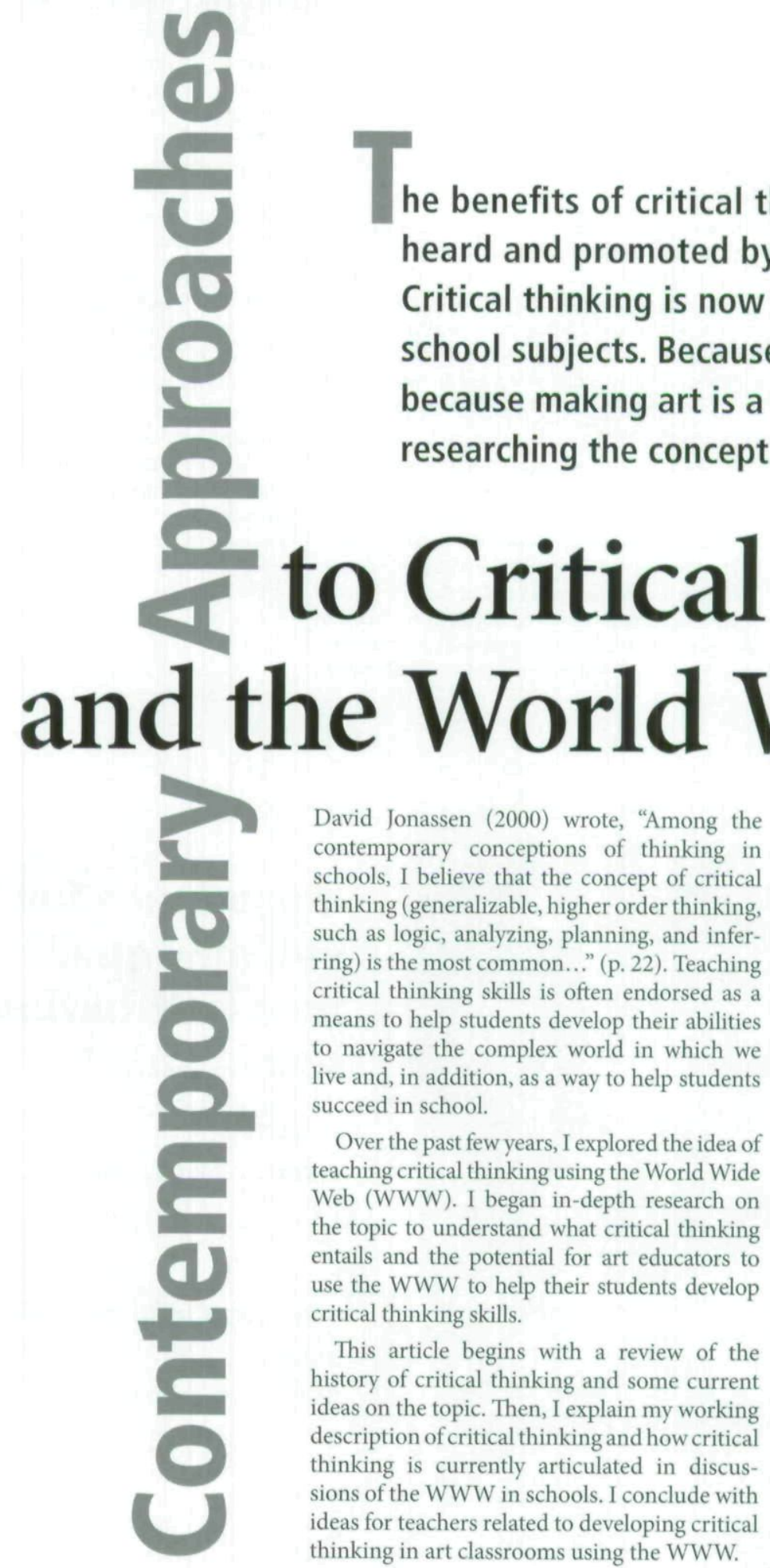


Figure 1. History of Critical Thinking

\begin{tabular}{|c|c|c|c|c|}
\hline & Phase 1 & Phase 2 & Phase 3 & Phase 4 \\
\hline Dates & 1910-1939 & 1940-1961 & 1962-1979 & 1980-1992 \\
\hline Proponents & John Dewey & $\begin{array}{l}\text { Edward Glaser, } \\
\text { David Russell, B. } \\
\text { Othanel Smith }\end{array}$ & $\begin{array}{l}\text { Robert Ennis, Karl } \\
\text { Budmen, R. Allen, Robert } \\
\text { Rott, Edward D'Angelo }\end{array}$ & $\begin{array}{l}\text { Robert Ennis, John } \\
\text { McPeck, Harvey } \\
\text { Siegel, Richard Paul }\end{array}$ \\
\hline $\begin{array}{l}\text { Common Terms } \\
\text { and Themes }\end{array}$ & $\begin{array}{l}\text { Reflective thought, } \\
\text { Scientific method, } \\
\text { Inquiry, Research }\end{array}$ & $\begin{array}{l}\text { Critical thinking, } \\
\text { Propaganda analysis, } \\
\text { Examining knowl- } \\
\text { edge while consid- } \\
\text { ering the evidence } \\
\text { to support the } \\
\text { knowledge }\end{array}$ & $\begin{array}{l}\text { Critical thinking as the } \\
\text { assessment of state- } \\
\text { ments, Critical thinking } \\
\text { as distinct from the } \\
\text { scientific method }\end{array}$ & $\begin{array}{l}\text { Evaluation of value } \\
\text { statements, Rational } \\
\text { thinking, Problem } \\
\text { solving }\end{array}$ \\
\hline
\end{tabular}

Adapted from Streib (1992)

The following review of literature from general education about using the WWW to development of critical thinking skills should be useful for art educators.

\section{Development of Critical Thinking}

James Streib (1992) traced the notion of critical thinking back to early Greek philosophers. In the more recent past, he identified four distinct phases in the ideas that constitute critical thinking. The first phase of the critical thinking movement lasted from 1910-1939 and emanated from John Dewey's (1910) writings on reflective thinking and the scientific method as the basis for thinking and inquiry. The second phase, 1940-1961, built on the work of Dewey and includes Edward Glaser (1941), David Russell (1941), and B. Othanel Smith (1953), the originator of the term "critical thinking." During this phase, the phrase critical thinking was used in relation to judging the accuracy of statements. The third phase, 1962-1979, involved narrowing the definition of critical thinking to focus on evaluating a statement as correct or incorrect and teaching students to come to "correct" conclusions based upon given information. Though it seems to contradict the idea of correct conclusions, this phase is when the role of creative thinking entered the discussion on critical thinking. The fourth phase Streib identified, 1980-1992, broadened the previous definitions and encompassed problem solving. This phase also addressed other related theories of cognition including higher order thinking, problem solving, and metacognition. In the years since Streib's study, new ideas about critical thinking have emerged; these are reviewed in the following section. (See Figure 1.)

\section{Recent Notions of Critical Thinking}

Richard Paul, a widely recognized contemporary authority on critical thinking, defined critical thinking as the following:

(1) Disciplined, self-directed thinking, which exemplifies the perfections of thinking appropriate to a particular mode or domain of thinking. (2)

Thinking that displays mastery of intellectual skills and abilities. (3) The art of thinking about your thinking while you are thinking in order to make your thinking better: more clear, more accurate, or more defensible.

(1995, p. 526)

Unlike earlier authors, Paul highlighted the metacognitive aspects of critical thinking. In a recent work, Richard Paul and Linda Elder (2004) wrote, "...critical and creative thought are intimately related. Each without the other is of limited use. Creativity without criticality is mere novelty. Criticality without creativity is bare negativity" (p. 21). The authors explained the inter-relationship they saw between critical and creative thinking.

Other contemporary authors emphasize different aspects of critical thinking including reflecting upon thoughts from various perspectives, considering the basis for the arguments of others, and recognizing the importance of systematic thinking (Browne, Freeman, \& Williamson, 2000; Cassel \& Congleton, 1993; Vidoni \& Maddux, 2002). Kimberly Vidoni and Cleborne Maddux (2002) found that critical thinking helps individuals learn about and understand their own thinking and to consider their own and others' thoughts from a variety of perspectives. Additionally, Jeris Cassel and Robert Congleton (1993) mentioned that instruction should, "encourage exposure, recognition, and acceptance of multiple viewpoints by individuals and encourage providing opportunities for individuals to use critical thinking" (p. viii). A recent example related to art education comes from a study of critical thinking underway at the Isabella Stewart Gardner Museum. In this study related to developing critical thinking through their School Partnership Program, the educators at the Isabella Stewart Gardner Museum developed a rubric to evaluate students' critical thinking skills. Their rubric includes the following criteria: observing, interpreting, evaluating, associating, problemfinding, comparing, and flexible thinking (Isabella Stewart Gardner Museum, 2006).

\section{If educational uses of the} $W W W$ are to fulfill even a fraction of the claims made when the movement to wire every school was in its heyday, then educators must continually evaluate developing trends with its use. 
Students will need to consider

the motivations of the different

sites and think about why the

different sites are promoting

different ideas. This type of

activity recognizes the existence

of a multiplicity of ideas and

could enable students to think

critically about why and how

people come to interpret works

of art in different ways.

\section{Working Description of Critical Thinking in Art}

These more recent descriptions of critical thinking are the most applicable to contemporary art education. Authors in arteducation also address critical thinking and its applications in K-12 art classroom and museum settings (Housen, 2002; Kader, 2003; Kowalchuk, 1999; Kundu \& Bain, 2006; Leshnoff, 1995; Milbrandt et al., 2004), however their descriptions of critical thinking vary. Thus, I created a working description based upon my readings:

Critical thinking involves considering an issue, a project, an idea, an artwork, or anything else from multiple perspectives. It is highly relevant to the process of creation, especially the iterative aspects of making things. It involves an awareness of the cyclical process of thinking, experimenting, creating, reflecting, recreating, and exhibiting, though does not have to involve all of these. Critical thinking relates to art criticism in more than linguistic ways and involves ideas of interpretation, the multiplicity of possible interpretations, and the awareness and understanding of the reasons for these varied interpretations.

With this description in mind, I investigated articles that promote critical thinking through the use of the WWW in public school settings in order to find ideas that were applicable for art education.

\section{Critical Thinking and the World Wide Web in Public Schools}

Many authors address the idea of using the WWW as a way to help students develop critical thinking skills. However, there is little agreement about what critical thinking is or how using the WWW will facilitate critical thinking.

\section{Authors' Descriptions of Critical Thinking}

Few of the articles I analyzed on critical thinking and the WWW for a K-12 audience clearly and carefully articulated a working description of critical thinking. ${ }^{2}$ In fact, the majority mentioned the term critical thinking without explaining its nuances and some authors did not offer any description of it whatsoever (Kids on the Net, 2002; Kurubacak \& Gonzales, 2002; Radlick, 2002; Taylor, 2002), an issue noted by Streib (1992). In general, the descriptions that authors use operate from the perspective that there is a widely accepted view of critical thinking, that critical thinking should be logical in nature, and that evaluating the validity of information from the WWW is of paramount importance. The lack of detailed descriptions of critical thinking is important because these articles promote different ideas ranging from merely deciding if a source is reliable to critically evaluating divergent information and choosing what to believe. Additionally, the lack of descriptions is problematic because teachers (presumably the audience for these articles) must consciously understand the type(s) of thinking that they are to teach. Without a clearly articulated description of what critical thinking entails, each individual is, essentially, working independently to infer the author's intended meaning.

\section{Activities Promoted in Critical Thinking Literature}

Numerous articles and books explore ideas that teachers can use in the classroom to help their students develop critical thinking skills. Among the ideas promoted, two commonly appear: fact-finding and, subsequently, using a "formula" to decide if information found on the WWW is trustworthy.

Few resources exist on using the World Wide Web to promote critical thinking specifically in art education. However, throughout the resources I identified, teaching students to find the correct answers on the WWW to specific questions emerged as a common theme (Eyerdam, 2003; Radlick, 2002; Salpeter, 2003). For example, Judy Salpeter (2003) mentioned the need for students to "hone fact-finding skills" (p. 2). Although premised on the idea of critical thinking, the types of activities promoted by this resource do not reinforce the complex types of critical thinking I described earlier. A second theme that emerged from numerous articles is the need to train students to determine the validity of the information they find on the WWW, and that this constitutes an example of critical thinking. Hermann Astleitner (2002) frequently used the term "training" to refer to ways students should learn to think critically with the WWW. The training is not limited to merely learning to use the WWW, it extends to formulaic ideas related to determining the perceived reliability of an information source on the WWW (Patterson, 2003; Salpeter, 2003). Though these are important skills, they do not reflect my previously stated working description of critical thinking. Instead, they are reflective of early conceptions of critical thinking limited to determining the accuracy of a statement, rather than reflecting about the reasons for the existence of divergent ideas.

James Shiveley (2004) provided more nuanced ideas related to evaluating the information on the WWW. He advocated more flexibility with regard to evaluating the content found on the WWW and urged teachers to help students use the variety of perspectives represented on websites as a learning tool. Shiveley believed that the existence of contradictory information on the WWW is an opportunity for students to learn critical thinking skills. He noted that this will help in the development of citizens who are prepared to participate in a pluralistic and democratic nation (Shiveley, 2004).

\section{Application Ideas}

From the literature related to using the World Wide Web to develop critical thinking skills, three ideas stand out as being particularly adaptable to art education: using the WWW to learn about controversial social issues, learning about conflicting interpretations of artworks, and WebQuests. These ideas could be modified to work with students at a variety of levels.

\section{Controversial Issues}

The first example comes from Joanne Harris (2003) who described a lesson related to critical thinking from a unit she taught on food biotechnology, a controversial social issue. The various stakeholders involved in either supporting or rejecting genetically modified foods have a significant amount of information posted on the WWW. Within this 
lesson, Harris had multiple objectives for her seventh- and eighth-grade students: gathering and thinking about divergent information on the WWW, evaluating the information they located, condensing large quantities of information, creating pamphlets using a graphic layout program, and sharing the finished product with other students.

Harris' students had no difficulty locating information; however, they found that often the information from different sources did not agree. This led some students to interview farmers and research scientists as well as to consult other print media regarding genetically modified foods. Students each created a pamphlet explaining their views on issues related to food technology based upon their research. Among their numerous learning experiences, three were particularly salient with regard to critical thinking. Students not only learned how to evaluate information they found, but they also learned that conflicts in existing information are not necessarily indicative of incorrect information, and that the creator of the website determined what the site presented as the truth. For instance, the agribusiness websites presented genetically modified foods as being safe, while the websites of environmental groups presented genetically modified foods as potentially harmful. Both types of sites can be deemed reliable, yet their conflicting information created a situation in which students had to decide what to believe and why.

Using Harris' process as a model, teachers could create art projects based around contemporary social issues of controversy that are well represented on the WWW. Students could use websites pre-selected by the teacher or find their own, investigate different points of view, and come to their own understanding of the issue. Then, students could create a website communicating their point of view on the issue, possibly using images the students create in graphics programs. Thus, students' artmaking could contribute to creating the WWW, instead of merely consuming it. Alternatively, students could create a painting, brochure, billboard, $t$-shirt, or other artwork that communicates their viewpoint. Contemporary artists are concerned with countless social issues including the environment, identity, body image, community, race, culture, technology, etc. Additionally, this idea could be adapted to focus specifically on issues relevant to museum practice, including the provenance of stolen Nazi-era art, the recent scandals involving the purchase of antiquities, the repatriation of objects, and many issues surrounding the display of objects. Students could work with websites that represent a variety of viewpoints on these issues and create artworks that reflect their developing understanding of the issue.

\section{Interpreting Artworks}

A second and related way teachers can involve students in critical thinking using the World Wide Web relates to the interpretation of artworks. As noted by Leshnoff (1995), teachers and students often have different experiences and different knowledge bases to draw upon when interpreting artworks. Instead of a traditional "art in the dark" approach to art history and art criticism, teachers should involve students in actively constructing their own ideas and understandings of artworks. Selecting artworks that have a variety of plausible interpretations that are available upon the WWW is a crucial step. Students can investigate the contexts of the artwork including the historical time in which it was made, the places the artwork has been exhibited, and the intention of the person who made the object.

Additionally, students could use museum websites as sources of "official" information about an object and compare and contrast these to other ideas about the artwork that are

\section{Among their numerous}

learning experiences, three were particularly salient with regard to critical thinking. Students not only learned how to evaluate information they found, but they also learned that conflicts in existing information are not necessarily indicative of incorrect information, and that the creator of the website determined what the site presented as the truth. represented on the WWW. Students will need to consider the motivations of the different sites and think about why the different sites are promoting different ideas. This type of activity recognizes the existence of a multiplicity of ideas and could enable students to think critically about why and how people come to interpret works of art in different ways. This clearly relates to the idea promoted by Jacqueline Chanda and Vesta Daniel (2000) in their article on ReCognizing works of art. They believed that students are likely to accept an interpretation that is easy to access or is comfortable. Through using the WWW, teachers can expose students to a variety of interpretations about artworks that may challenge students' comfort zones and cause them to reflect upon why these divergent ideas may exist. Developing a knowledge base about an artwork and then thinking about different interpretations of the artwork allows students to think critically about the meaning of the artwork.

\section{WebQuests}

WebQuests constitute a third means for integrating the WWW and critical thinking skills in the art classroom. Authors describe the emerging uses of WebQuests ${ }^{3}$ to build student critical thinking skills (Kundu \& Bain, 2006; Vidoni \& Maddux. 2002; Young \& Wilson, 2002). The concept of a WebQuest was first articulated by Bernie Dodge in 1995 (1995, 2000) and refers to inquiry-oriented activities for students that develop higher-order thinking skills using websites as information sources. WebQuests have a specified format to guide student inquiry; the sections include an introduction, task, process, resources, evaluation, and conclusion. Despite their name, well-developed WebQuests require more than information gathering; students must also process, evaluate, and synthesize the information to form their own conclusions. Often, WebQuests involve students working collaboratively and culminate in a class discussion, presentation, structured debate, creation of an art project, or another activity connected to classroom interaction.

A good WebQuest focuses on an issue that has multiple viewpoints represented on the Web, such as a social, political, environmental, or health related issue. Though there are numerous authors who writeabout WebQuests, they rarely focus on visual arts WebQuests. One exceptional WebQuest page was created by the Whitney Museum of American Art and addresses the work of Jacob Lawrence 


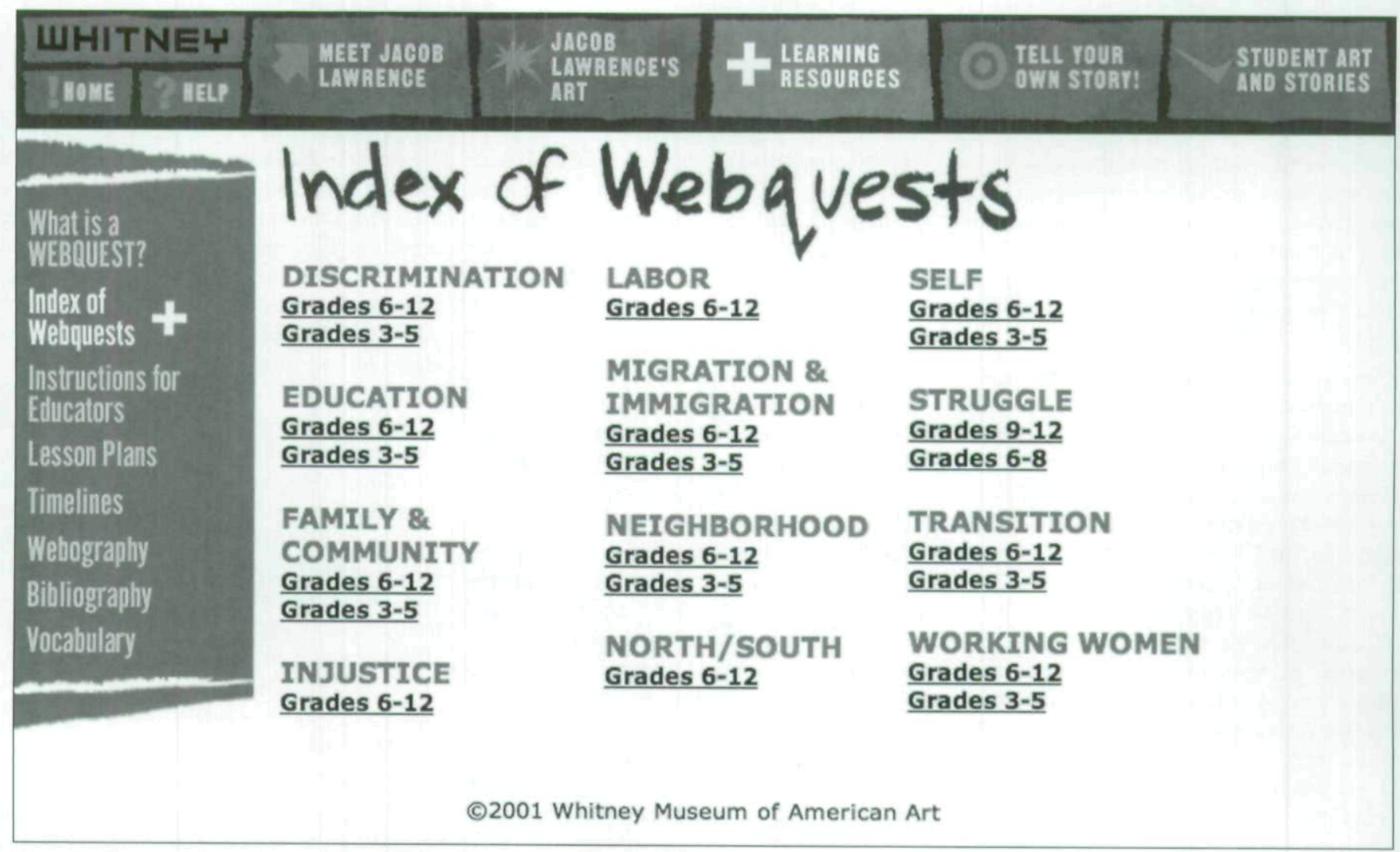

"Learning Resources." Jacob Lawrence: Exploring Stories, Whitney Museum of American Art, N.Y., November 8, 2001. www.whitnew.org/jacoblawrence/resources/webqst_index.html. @2001 Whitney Museum of American Art.

(http://www.whitney.org/jacoblawrence/ resources/webqst_index.html). Through the numerous WebQuests on this site, students can investigate a variety of issues related to Lawrence's work including working women, struggle, transition, migration, family and community, and discrimination.

\section{Conclusions}

I have suggested that the ideas promoted in the recent published literature on critical thinking and the WWW do not explicitly relate to contemporary ideas about critical thinking. Additionally, there is little continuity or agreement among the articles as to what critical thinking is. As art educators, we need to create working descriptions of critical thinking that can guide our practices and conscientiously work to involve our students in lessons that involve critical thinking. If we can be successful in these goals, then we may help students learn more about the world beyond the classroom and help students think as they investigate topics through the WWW. For teachers to be successful in integrating critical thinking and the WWW, they should be prepared for the following scenarios:
- Students will likely come to different conclusions and may need to learn how to disagree without being disagreeable;

- Students' questions and ideas may lead to other questions and ideas, and not necessarily to an answer;

- Without sufficient guidance, student use of the WWW may be superficial, at best, and mainly involve surfing commercial sites;

- You may wish to generate lists of preselected sites for students to use as a starting point. This is especially beneficial for younger students and those who do not have considerable experience locating information on the WWW; and

- Try incorporating a critical thinking activity involving the WWW into a lesson you enjoy teaching and that you know is already successful with students. Starting with an established lesson and adding a WWW component may increase your chances of having a successful experience.

Continually rethinking and refining what we do to involve recent technology and contemporary ideas will not only help prepare our students for their roles in society, but will also help art teachers stay invigorated and excited about their profession.
Melanie L. Buffington is assistant professor, Department of Art Education, School of the Arts, Virginia Commonwealth University, Richmond. E-mail: mbuffington@vcu.edu

\section{REFERENCES}

Astleitner, H. (2002). Teaching critical thinking online. [Electronic version]. Journal of Instructional Psychology, 1-32.

Browne, M., Freeman, K., \& Williamson, C. (2000). The importance of critical thinking for students' use of the Internet. College Student Journal, 34(3), 391-398.

Cassel, J. F., \& Congleton, R. J. (1993). Critical thinking: An annotated bibliography. Metuchen, NJ: The Scarecrow Press.

Chanda, J., \& Daniel, V. (2000). (Re)Cognizing works of art. Art Education, 53(2), 6-11.

Cuban, L. (2001). Oversold and underused: Computers in the classroom. Cambridge, MA: Harvard University Press.

Dewey, J. (1910). How we think. Boston: D.C. Heath.

Dodge, B. (1995). Some thoughts about web quests. Retrieved March 7, 2002, from http://edweb. sdsu.edu/courses/edtec596/about_webquests. html.

Dodge, B. J. (2000, June). Thinking visually with WebQuests. Presentation at the National Educational Computing Conference, Atlanta, GA. Retrieved March 7, 2002 from http:// edweb.sdsu.edu/Webquest/tv/. 
Efland, A. (2002). Art and cognition: Integrating the visual arts in the curriculum. New York: Teachers College Press.

Eyerdam, P. J. (2003). Using Internet primary sources to teach critical thinking skills in visual arts. Westport, CT: Libraries Unlimited.

Glaser, E. M. (1941). An experiment in the development of critical thinking. New York: Teachers College Press.

Harris, J. (2003). The skeptical surfer: Web research and critical thinking on controversial issues, Green Teacher, 70, 21-24.

Housen, A. (2002). Aesthetic thought, critical thinking and transfer. Arts and Learning Research Journal, 18 (1), 99-132.

Isabella Stewart Gardner Museum. (2006). Retrieved April 24, 2006, from http://www. gardnermuseum.org/education/gardner.html.

Jonassen, D. H. (2000). Computers as mindtools for schools: Engaging critical thinking. Upper Saddle River, NJ: Merrill.

Kader, T. (2003). Material culture studies and art education: Connecting artifacts with making art. Art Education, 56(5), 19-14.

Kids on the Net. (2002). Retrieved May 12, 2002, from http://www.media-awareness.ca/eng/med/ class/kidsnet 7 .htm

Kowalchuk, E. (1999). Recognizing and using higher order approaches to teaching art. Art Education, 52(6), 13-18.

Kundu, R., \& Bain, C. (2006). Webquests: Utilizing technology in a constructivist manner to facilitate meaningful preservice learning. Art Education, 59(2), 6-11.

Kurubacak, G., \& Gonzales, C. (2002). The use of the Internet to teach critical thinking. Presentation at the Society for Information technology and Teacher Education International Conference, Nashville, TN. (ERIC Document Reproduction Service No. ED 472253).

Leshnoff, S. K. (1995). Art, ambiguity and critical thinking. Art Education, 48 (5), 51-56.

Milbrandt, M. K., Felts, J., Richards, B., \& Abghari, N. (2004). Teaching-to-learn: A constructivist approach to shared responsibility. Art Education, 57 (5), 19-24,33.

Patterson, N. (2003). Becoming literate in the ways of the web: Evaluating Internet resources. Voices from the Middle, 10(3), 58-59.

Paul, R. (1995). Critical thinking: How to prepare students for a rapidly changing world. Rohnert Park, CA: Center for Critical Thinking and Moral Critique.

Paul, R., \& Elder, L. (2004). The thinker's guide to the nature and functions of critical and creative thinking. The Foundation for Critical Thinking.

Radlick, M. (2002). Do they know what they're downloading? A study of how people determine the validity of information from the Internet. Unpublished master's thesis. Grand Valley State University, MI
Russell, D. (1941). Education for critical thinking. The School, 30, 188-194.

Salpeter, J. (2003). Web literacy and critical thinking: A teacher's tool kit [Electronic version]. Technology o Learning, 23(8).

Shiveley, J. M. (2004). Critical thinking and visiting websites: It must be elementary! Social Studies and the Young Learner, 16(4), 9-12.

Short, G. (1995). Understanding domain knowledge for teaching: Higher-order thinking in pre-service art teacher specialists. Studies in Art Education, 36(3), 154-169.

Smith, B. O. (1953). The improvement of critical thinking. Progressive Education, $30,129-134$

Stout, C. J. (1995). Critical conversations about art: A description of higher-order thinking generated through the study of art criticism. Studies in Art Education, 36(3), 170-188.

Streib, J. (1992). History and analysis of critical thinking. Unpublished doctoral dissertation. Memphis State University, Tennessee.

Taylor, A. (2002). Keeping up with the kids in a wired world. MultiMedia Schools, 9(2), 40-43.

Vidoni, K. L., \& Maddux, C. D. (2002). WebQuests: Can they be used to improve critical thinking skills in students? Computers in the Schools, 19(1/2) 101-117.

Walker, S. R. (1996). Thinking strategies for interpreting artworks. Studies in Art Education, 37(2), 80-91

Young, D. L., \& Wilson, B. G. (2002). WebQuests for reflection and conceptual change: Variations on a popular model for guided inquiry. Presentation at the EdMedia Conference, Denver, CO. Retrieved April 14, 2006, from http://carbon. cudenver.edu/ bwilson/WebQuest/

\section{ENDNOTES}

${ }^{1}$ Critical thinking is also referred to as "higher order thinking" and "understanding" by different authors.

${ }^{2}$ Numerous articles written about applications of critical thinking curricula in higher education settings include detailed descriptions of the concept.

${ }^{3}$ See the WebQuest page at the San Diego State University's website: www.sdsu. edu/webquest for further information and examples of WebQuests.

\section{Cabl FOI Ebtries!}

Robert Rauschenberg Day The Power of Art: Teaching Students with Learning Disabilities

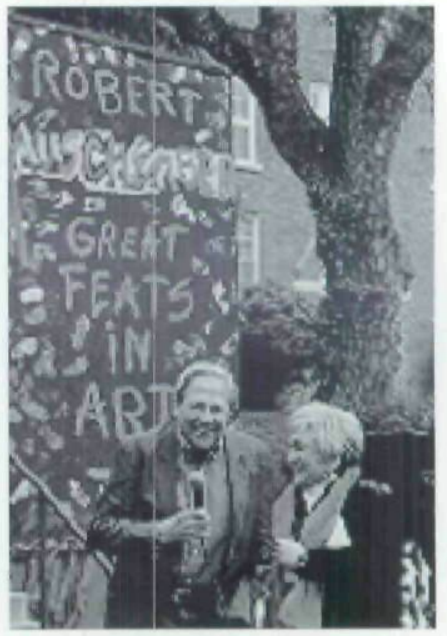

A comprehensive one day workshop, held on Friday May 18, 2007, for art teachers who work with students with learning disabilities. This program presents the exciting and innovative ways the arts can be used to teach academic skills to students with learning disabilities.

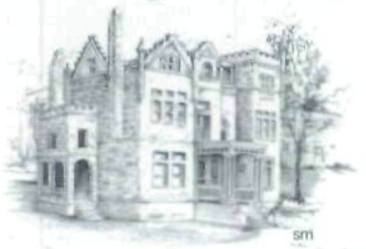

CALL 202.965.6600 TO RECEIVE INFORMATION ABOUT APPLYING FOR THIS UNIQUE WORKSHOP. THE APPLICATION FORM CAN ALSO BE DOWNLOADED DIRECTLY FROM OUR WEBSITE: WWW.LABSCHOOL.ORG or e-mail: emily.marchetti@labschool.org DEADLINE: To be announced. 